\title{
The association between dietary protein intake and bone mass accretion in pubertal girls with low calcium intakes
}

\author{
Qian Zhang ${ }^{1}$, Guansheng $\mathrm{Ma}^{1}$, Heather Greenfield ${ }^{2}$, Kun $\mathrm{Zhu}^{2}$, Xueqin $\mathrm{Du}^{2}$, Leng Huat $\mathrm{Foo}^{2}$, Xiaoqi $\mathrm{Hu}^{1}$ \\ and David R. Fraser ${ }^{2}$ \\ ${ }^{1}$ National Institute for Nutrition and Food Safety, Chinese Centre for Disease Control and Prevention, Beijing, China \\ ${ }^{2}$ Faculty of Veterinary Science, University of Sydney, Sydney, Australia \\ (Received 10 February 2009 - Revised 4 September 2009 - Accepted 4 September 2009 - First published online 9 October 2009)
}

To assess the association between protein intakes and bone mass accrual in girls, data were analysed for 757 pre-pubertal girls (mean age $10 \cdot 1$ years) in urban Beijing, China, who participated in a 5-year study including 2 years of milk supplementation (intervention groups only) and 3 years of follow-up study. At 0, 12, 24, 48 and 60 months from the baseline, bone mass of the proximal or distal forearm (PF or DF) and total body (TB) was measured with dual energy X-ray absorptiometry; dietary intakes were assessed by a 3-d food record (including two weekdays and one weekend day). Linear mixed models were used and continuous variables were logarithm transformed. The mean longitudinal Ca intake $(432-675 \mathrm{mg} / \mathrm{d}$ on average) positively influenced bone mineral content (BMC) at TB, PF and DF after controlling for baseline bone mass and other possible confounders. However, negative associations were observed between protein intake $(55.9-61 \cdot 0 \mathrm{~g} / \mathrm{d}$ on average) and BMC accrual at TB, PF or DF $(\beta=-1.92,-10.2$ or -4.82 , respectively, $P<0.01)$ after adjustment. When protein intake was considered according to animal or plant food sources, protein from animal foods, particularly meat, had significant negative effects on BMC accrual at DF or PF after adjustment. It was concluded that higher protein intake, especially from animal foods, appeared to have a negative effect on bone mass accrual in Chinese pubertal girls with low $\mathrm{Ca}$ intakes.

Girls: Protein: Calcium: Bone mass accrual

The prevalence of osteoporosis has been increasing in recent years because of increases in life expectancy and in the proportion of older individuals in most countries ${ }^{(1)}$. An effective and economical approach to reducing the incidence of osteoporosis is to increase bone mass accrual during childhood and adolescence to achieve optimal peak bone mass. Childhood and adolescence are critical periods for bone mass accrual since more than $50 \%$ of peak bone mass is accumulated during this period ${ }^{(2)}$. Low bone mass accrual during childhood and adolescence has been shown to increase not only the risk of osteoporosis in old age $\mathrm{a}^{(3-5)}$ but also the incidence of fracture during childhood ${ }^{(6)}$.

Although about $60-80 \%$ of the variability of bone mass accrual during childhood and adolescence could be explained by heritable factors ${ }^{(7)}$, the genetic potential is reached only if the modifiable environmental factors are optimal. Among environmental factors, suitable nutrient intakes, especially sufficient $\mathrm{Ca}$ intake, are the basis for maximum bone mass accrual. However, dietary $\mathrm{Ca}$ intakes in children are very low in some countries. For instance, in China, it was only $334 \mathrm{mg} / \mathrm{d}$ for urban girls aged 11-13 years according to the 2002 China National Nutrition and Health Survey ${ }^{(8)}$. This was much lower than the recommended adequate intake ( $1000 \mathrm{mg} / \mathrm{d}$ for this age group), suggested by the dietary recommended intakes of the Chinese Nutrition Society published in $2000^{(9)}$. Although children with habitual low $\mathrm{Ca}$ intakes appear to increase absorption and decrease excretion of $\mathrm{Ca}$ during puberty ${ }^{(10)}$, the data of Abrams et al. ${ }^{(11)}$ indicate that dietary Ca intakes less than $500 \mathrm{mg} / \mathrm{d}$ were far from enough for adequate $\mathrm{Ca}$ retention or optimal bone mass accrual. Whether habitual low $\mathrm{Ca}$ intake would influence the bone mass accrual in Chinese children needs further research.

The intake of other nutrients, such as protein, might also have an effect on bone mass accretion. Although dietary protein supplies the amino acid substrates for the protein of bone matrix, any quantitative relationship between protein intake and bone mass remains uncertain. Several studies have indicated a negative ${ }^{(13,14)}$ or positive ${ }^{(15,16)}$ influence of protein on $\mathrm{Ca}$ balance in postmenopausal women. However, understanding of how protein affects bone mass accrual in children and adolescents is limited to data for Western children on high $\mathrm{Ca}$ diets ${ }^{(12,17)}$ with little information available about children with low $\mathrm{Ca}$ intakes. The purpose of the present study was to assess whether there was any relationship between dietary nutrient intakes, especially protein intake, and bone mass accrual in Chinese adolescent girls, who had low habitual $\mathrm{Ca}$ intakes.

Abbreviations: BA, bone area; BMC, bone mineral content; BMD, bone mineral density; PA, physical activity; PRAL, potential renal acid load.

* Corresponding author: Dr Qian Zhang, fax +86108313 2021, email zhangq-99@263.net 


\section{Subjects and methods}

Subjects

Pre-pubertal girls $(n$ 757) with a mean age of $10 \cdot 1$ years at baseline were recruited from nine primary schools in urban of Beijing, China, for a 2-year milk supplementation trial ${ }^{(18)}$ and 3 -year follow-up study ${ }^{(19)}$. They were free from any disease that might influence their bone growth and development. During an intervention study in 1999-2001, they were randomly divided into three groups of comparable socio-economic status according to their school. Two groups were supplied with either $330 \mathrm{ml} \mathrm{Ca-fortified} \mathrm{milk} \mathrm{(} n$ 238) or milk fortified with Ca and vitamin $\mathrm{D}$ ( $n$ 260) on each school day for 24 months. The third group acted as controls and consumed their habitual diet without milk supplementation ( $n$ 259) during the same period. The milk supplement contained $(\mathrm{g} / \mathrm{l})$ : Ca $1 \cdot 7$, protein 30 , fat 30 , sucrose 20 and lactose less than 50 . After adjustment for weekends and holidays, each subject in the two supplemented groups consumed on average $144 \mathrm{ml} / \mathrm{d}$ supplementary milk, containing Ca $245 \mathrm{mg} / \mathrm{d}$ and protein $4.3 \mathrm{~g} / \mathrm{d}$ with/without vitamin D $3.33 \mu \mathrm{g} / \mathrm{d}^{(18)}$. In the follow-up study, 505 out of the 698 subjects who completed the 2-year supplementation trial were available at 36 months after supplement withdrawal, that is, 60 months from the baseline, in 2004. They were by then enrolled in twenty-six secondary schools, ranging from one to fifty-six subjects in each school ${ }^{(19)}$.

The present study was conducted according to the guidelines laid down in the Declaration of Helsinki, and all procedures involving human subjects were approved by the Ethics Committees of the University of Sydney, and the Institute of Nutrition and Food Hygiene of the Chinese Academy of Preventive Medicine (now the National Institute for Nutrition and Food Safety, Chinese Centre for Disease Control and Prevention). Written informed consent was obtained from all subjects.

\section{Bone mass}

Bone mass was measured at 0, 12, 24, 48 and 60 months from the baseline with dual energy X-ray absorptiometry and analysed with software version 3.94 (Norland XR-36; Norland Medical Systems, Inc., Norland, Fort Atkinson, WI, USA) at the Department of Nuclear Medicine, 304 Hospital, Beijing. The densitometer had a variation in precision of $<1.0 \%$ for the measured bone site at standard speed. A daily quality assurance test was performed over the study period with the use of a hydroxyapatite phantom (as supplied by the manufacturer), resulting in an accuracy error rate of $<1.0 \%$. Subjects wore T-shirts and shorts without any metal objects during the measurement process.

Bone mineral content (BMC), bone area (BA) and bone mineral density (BMD) were measured at the distal and proximal forearm of the non-dominant arm in all subjects, and at the whole body in half of the subjects selected at random. The starting point of the distal forearm measurement scan for each subject was determined by XR software using the minimum BMD value found during the first forearm scout scan. A numeric value of $33 \%$ for the total length of the ulna (i.e. the distance from the ulnar end plate) was calculated by XR software and then determined as the starting point for the proximal forearm measurement scan.

\section{Dietary assessment}

Dietary intakes were assessed by a seven-consecutive-day food record at the baseline and a three-consecutive-day food record (including two weekdays and one weekend day) at 6 , 12, 24, 48, 54 and 60 months from the baseline. Change from a 7-d food record to a 3-d food record was designed to improve the compliance of subjects. The correlation coefficient between the two methods was $0.784-0.883$ as calculated for eighty-nine subjects selected at random from the nine schools during the baseline study ${ }^{(18)}$.

Before each survey, instructions on how to complete the dietary record were given in detail, including illustrating the portions and sizes of each dish. Subjects recorded their own dietary intake with some help from their parents if needed. All the food records were verified by interviewing each subject about their diets. Chinese measurements of bowls, plates and spoons, being of standard size, were used to quantify food with the assistance of food-measuring models. Nutrient intakes were calculated from the Chinese food composition tables ${ }^{(20)}$. The vitamin D content of food was estimated from the UK food composition tables ${ }^{(21)}$ and adjusted downwards for vitamin D in eggs and in fortified fresh milk based upon local analyses of these foods ${ }^{(20-22)}$. Milk supplied for the two intervention groups during the first 2 years of intervention was included in calculating the dietary nutrient intakes.

Food sources of protein in each survey were categorised into thirteen groups, primarily as referred to in the 2002 China National Nutrition and Health Survey ${ }^{(8)}$, namely cereals, legumes, vegetables, fruits, nuts, candies, beverages, ice confections and condiments as plant sources, and meats, eggs, seafood, milk and milk products as animal sources. Nutrient intakes or protein sources at 0,24 and 48 months since the baseline were related to bone mass measured at the same time. Dietary intakes at 6 and 12 months since baseline were averaged and related to bone mass measured at 12 months. Dietary intakes at 54 and 60 months since baseline were averaged and related to bone mass measured at 60 months. Milk supplied for the two intervention groups was treated as a covariate in multiple regression analyses and included when calculating dietary intakes. Three cooperating observers (Q. Z., K. Z. and X. D.) conducted the dietary surveys using the same methods.

\section{Other measurements}

The ratio of $\mathrm{Ca}$ to protein (Ca:protein, $\mathrm{mg}: \mathrm{g}$ ) in the diet was calculated at each dietary survey. Dietary acid load was estimated as potential renal acid load (PRAL) by using the following algorithm ${ }^{(12)}$ :

$$
\begin{aligned}
\operatorname{PRAL}(\mathrm{mEq} / \mathrm{d})= & 0.4888 \times \operatorname{protein}(\mathrm{g} / \mathrm{d}) \\
& +0.0366 \times \mathrm{P}(\mathrm{mg} / \mathrm{d}) \\
& -0.0205 \times \mathrm{K}(\mathrm{mg} / \mathrm{d}) \\
& -0.0263 \times \mathrm{Mg}(\mathrm{mg} / \mathrm{d}) .
\end{aligned}
$$

Physical activity (PA) was determined from a 6-month PA questionnaire at 0,12 and 24 months after baseline with regard to leisure activity PA and PA from training at sports clubs or 
teams. A 12-month PA questionnaire estimated PA at 48 and 60 months since baseline and extended the original questionnaire to cover leisure activities, school-organised activities and any training ${ }^{(23)}$. To control for differences in the questionnaires, total PA was expressed as PA metabolic equivalents $(\mathrm{kJ} / \mathrm{kg} \text { per week })^{(24,25)}$ and their percentage distribution at each survey.

Anthropometry and pubertal development were assessed at $0,12,24,48$ and 60 months from the baseline. Body weight was measured with an electronic digital scale (Thinner, Fairfield, WI, USA) while wearing light clothing and no shoes; height was measured with a body height measuring device (TG-III Type, No. 6; Machinery Plant, Beijing, China) in bare feet. Breast and pubic hair development were assessed in accordance with Tanner's definition of the five stages of puberty ${ }^{(26)}$; information about menstrual status and date of menarche was collected during each interview.

The second voiding morning urine samples were collected in 133 subjects at baseline and in 227 subjects at 12 months after baseline, randomly selected from all subjects. Urine samples were stored at $-20^{\circ} \mathrm{C}$ before being shipped in solid $\mathrm{CO}_{2}$ to Australia for analysis at the University of Sydney. The total $\mathrm{Ca}$ concentration in urine was determined using an arsenazo III spectrophotometric method (Cobas MIRA Roche Diagnostica, Basle, Switzerland). Urinary creatinine was measured by the Beckman Clinical Systems (Synchron CX5; Beckman Coulter, Inc., Fullerton, CA, USA) enzymatic method. Urine $\mathrm{Ca}$ and creatinine concentrations were expressed as Ca:creatinine ratio $(\mathrm{mmol} / \mathrm{mmol})$.

\section{Statistical analyses}

Data were entered using SPSS (version 12.0; SPSS Inc., Chicago, IL, USA) and Epi Info (version 6; WHO/CDC, Atlanta, GA, USA), and statistical analysis was conducted with Statistical Analysis Systems for Windows NT (version 8.00, 1999; SAS Institute, Inc., Cary, NC, USA). To describe information in each survey, means and standard deviations were applied for normal distribution data, while median, as well as 25th and 75th percentiles, was applied for nonnormal distribution data, unless otherwise stated.

The effect of nutrient intakes on bone mass was analysed by linear mixed models (PROC MIXED in SAS program) for longitudinal analysis. In the model, the dependent variable was the bone mass at each survey point. The main independent variables included nutrient intakes at each survey, baseline bone mass and pubertal development, as well as age and PA level at each survey. Other independent variables included the school attended as a random effect for clustering design and the time of the repeated measurements for each subjects ${ }^{(27)}$. Groups supplied with milk or serving as controls during the first 2 years of intervention period, time and the interaction between group and time were entered into the model as covariates ${ }^{(27)}$.

Continuous variables were logarithm transformed to observe the proportional association and to correct a skewed distribution of continuous variables. The regression coefficient $(\beta)$ of continuous variables, after being multiplied by 100 , corresponded closely with the percentage change in the dependent variable associated with each $100 \%$ change in the independent variable after adjustment for other confounders ${ }^{(28)}$.
Therefore, results of the regression analysis could be interpreted as, for example, doubling the $\mathrm{Ca}$ intake would theoretically result in a $0.82 \%$ increment in BMC of the total body according to the model suggested by Cole ${ }^{(28)}$.

All nutrient intakes were included in the initial model, followed by backward elimination with $P \leq 0 \cdot 1$ as the standard for retention. All subjects from all groups and subjects from the control groups (representing typical urban girls in China at puberty) were analysed separately to identify the influential components. In all of these analyses, results with $P$ values less than 0.05 were considered as statistically significant, while a $P$ value between 0.05 and 0.1 was considered as approaching significance or marginal significance. Similar methods were used to analyse the food source of protein on bone mass accrual after control for $\mathrm{Ca}$ intake and other potential confounders.

\section{Results}

The mean age of the subjects was 10.1 (SD 0.4) year at baseline, and 15.0 (SD 0.4) year at the end of study. During the 5-year study, the average dietary intakes were only 454 (SD 182) $\mathrm{mg} / \mathrm{d}$ for $\mathrm{Ca}$ and 55.9 (SD 16.4) $\mathrm{mg} / \mathrm{d}$ for protein in the control group who represented typical urban girls in China at puberty. For the two intervention groups, their $\mathrm{Ca}$ and protein intake reached $774.8(\mathrm{SD} 183.1) \mathrm{mg} / \mathrm{d}$ and $61.0(\mathrm{SD} \mathrm{16.3)} \mathrm{g} / \mathrm{d}$, respectively, during the supplementation period, and only 452.5 (SD 189.8) $\mathrm{mg} / \mathrm{d}$ and 55.0 (SD 16.9) g/d, respectively, during the follow-up period. For all subjects, their average total body bone mass accretion was 958 (SD 154) g, rising from 1332 (SD 200) $\mathrm{g}$ at baseline to 2290 (SD 266) g 5 years later with an increase of $71.9 \%$. Other physical characteristics, nutrient intakes and PA level at each survey are presented in Table 1 .

After 2 years of milk supplementation, significant differences were observed between the two supplied groups and the control group for $\mathrm{TB} \mathrm{BMC}^{(18)}$. However, the difference between groups became non-significant 3 years after supplement withdrawal ${ }^{(19)}$. These results have been published elsewhere $^{(18,19)}$.

\section{Nutrient intakes and bone mass accrual}

In order to shed light on the relationship between diet and bone mass accrual of Chinese pubertal girls, a linear mixed model with backward elimination regression was used to identify and quantify the influential components of longitudinal nutrient intakes of all subjects after adjusting for baseline bone mass and other potential confounders, including baseline pubertal development, age and PA percentage distribution at each survey, survey time, group, the interaction between time and group and clustering by schools (model 1 in Table 2).

As shown in Table 2, the total diet $\mathrm{Ca}$ intake positively influenced $\mathrm{BMC}$ accrual at TB $(\beta=0.92, P=0.04)$, PF $(\beta=5.72, P<0.01)$ and $\mathrm{DF}(\beta=2.59, P<0.01)$, BA accrual at $\mathrm{PF}(\beta=6.57, P<0.01)$ and $\mathrm{DF}(\beta=1.36, P=0.02)$, as well as BMD accrual at DF $(\beta=1 \cdot 72, P<0.01)$. However, negative associations were observed between diet protein intake and $\mathrm{BMC}$ accrual at $\mathrm{TB}(\beta=-1.92, \quad P=0.02)$, 
Table 1. The characteristics of all subjects from baseline to the end of study

(Mean values and standard deviations)

\begin{tabular}{|c|c|c|c|c|c|c|c|c|c|c|}
\hline & \multicolumn{2}{|c|}{ Baseline } & \multicolumn{2}{|c|}{12 months later } & \multicolumn{2}{|c|}{24 months later } & \multicolumn{2}{|c|}{48 months later } & \multicolumn{2}{|c|}{60 months later } \\
\hline & Mean & SD & Mean & SD & Mean & SD & Mean & SD & Mean & SD \\
\hline$n$ & \multicolumn{2}{|c|}{757} & \multicolumn{2}{|c|}{716} & \multicolumn{2}{|c|}{698} & \multicolumn{2}{|c|}{294} & \multicolumn{2}{|c|}{504} \\
\hline Age (years) & $10 \cdot 1$ & 0.4 & $11 \cdot 1$ & 0.3 & $12 \cdot 1$ & 0.3 & $14 \cdot 0$ & 0.3 & $15 \cdot 0$ & 0.4 \\
\hline Height (cm) & $140 \cdot 7$ & 6.5 & $147 \cdot 6$ & $6 \cdot 9$ & $153 \cdot 8$ & $6 \cdot 4$ & $159 \cdot 7$ & $5 \cdot 7$ & $161 \cdot 6$ & $5 \cdot 6$ \\
\hline Weight (kg) & 33.2 & $6 \cdot 8$ & 39.6 & 8.6 & 45.0 & $9 \cdot 2$ & $52 \cdot 8$ & $10 \cdot 9$ & $55 \cdot 1$ & $9 \cdot 8$ \\
\hline \multicolumn{11}{|l|}{ Total body } \\
\hline $\mathrm{BMC}(\mathrm{g})$ & 1332 & 200 & 1597 & 263 & 1864 & 263 & 2160 & 287 & 2290 & 266 \\
\hline $\mathrm{BA}\left(\mathrm{cm}^{2}\right)$ & 1931 & 172 & 2117 & 197 & 2524 & 205 & 2484 & 161 & 2543 & 152 \\
\hline BMD $\left(\mathrm{g} / \mathrm{cm}^{2}\right)$ & 0.687 & 0.053 & 0.750 & 0.065 & 0.738 & 0.081 & 0.867 & 0.075 & 0.899 & 0.074 \\
\hline \multicolumn{11}{|l|}{ Distal forearm } \\
\hline BMC (g) & 0.654 & 0.094 & 0.732 & 0.126 & 0.932 & 0.251 & 1.031 & 0.179 & $1 \cdot 140$ & 0.169 \\
\hline $\mathrm{BA}\left(\mathrm{cm}^{2}\right)$ & $2 \cdot 828$ & 0.219 & 2.953 & 0.255 & 3.331 & 0.436 & 3.444 & 0.268 & 3.625 & 0.247 \\
\hline $\operatorname{BMD}\left(\mathrm{g} / \mathrm{cm}^{2}\right)$ & 0.231 & 0.027 & 0.248 & 0.033 & 0.277 & 0.046 & 0.298 & 0.041 & 0.314 & 0.039 \\
\hline \multicolumn{11}{|l|}{ Proximal forearm } \\
\hline $\mathrm{BMC}(\mathrm{g})$ & 0.960 & 0.127 & 1.087 & 0.151 & 1.540 & 0.315 & 1.400 & 0.166 & 1.463 & 0.156 \\
\hline $\mathrm{BA}\left(\mathrm{cm}^{2}\right)$ & 2.007 & 0.132 & $2 \cdot 041$ & 0.137 & 2.996 & 0.796 & $2 \cdot 123$ & 0.151 & $2 \cdot 151$ & 0.137 \\
\hline $\operatorname{BMD}\left(\mathrm{g} / \mathrm{cm}^{2}\right)$ & 0.478 & 0.049 & 0.532 & 0.058 & 0.528 & 0.081 & 0.659 & 0.055 & 0.679 & 0.051 \\
\hline Physical activity level $(\mathrm{kJ} / \mathrm{kg}$ per week)* & $130 \cdot 6$ & $55 \cdot 9,265 \cdot 0$ & $122 \cdot 2$ & $69 \cdot 3,204 \cdot 9$ & $76 \cdot 4$ & $42 \cdot 8,138 \cdot 2$ & 155.8 & $94 \cdot 1,259 \cdot 1$ & $176 \cdot 8$ & $13 \cdot 8,271 \cdot 3$ \\
\hline \multicolumn{11}{|l|}{ Breast development† } \\
\hline 1 & 328 & 43.5 & 115 & $16 \cdot 1$ & 34 & $4 \cdot 86$ & 0 & 0.0 & 0 & 0.0 \\
\hline II and III & 426 & $56 \cdot 5$ & 583 & $81 \cdot 6$ & 570 & 81.4 & 49 & $16 \cdot 6$ & 19 & 3.8 \\
\hline IV and V & 0 & 0.0 & 16 & $2 \cdot 24$ & 96 & 13.7 & 245 & 83.3 & 481 & $96 \cdot 2$ \\
\hline Milk and milk products (g/d) & 149.9 & $100 \cdot 7$ & $298 \cdot 7 \ddagger$ & 263.5 & $293.9 \ddagger$ & $261 \cdot 8$ & $202 \cdot 4$ & $126 \cdot 0$ & $190 \cdot 7$ & 139.3 \\
\hline Energy $(\mathrm{kJ} / \mathrm{d})$ & 5716 & 1365 & $6112 \S$ & 1400 & $6503 \S$ & 1568 & 6354 & 1776 & 5762 & 1516 \\
\hline \multicolumn{11}{|l|}{ Protein } \\
\hline$g / d$ & $53 \cdot 7$ & $16 \cdot 2$ & $58.4 \S$ & $16 \cdot 2$ & $60 \cdot 3 \S$ & $16 \cdot 7$ & $60 \cdot 4$ & 17.9 & 54.5 & $16 \cdot 3$ \\
\hline $\mathrm{g} / \mathrm{kg}$ & 1.67 & 0.58 & $1.54 \S$ & 0.53 & $1.39 \S$ & 0.47 & $1 \cdot 19$ & 0.41 & 1.02 & 0.35 \\
\hline Protein from animal food $(\mathrm{g} / \mathrm{d})$ & $27 \cdot 6$ & $12 \cdot 8$ & $35.4 \S$ & 13.4 & $34.6 \S$ & $13 \cdot 4$ & 33.4 & 14.4 & $30 \cdot 3$ & $13 \cdot 0$ \\
\hline Protein from plant food $(\mathrm{g} / \mathrm{d})$ & $26 \cdot 2$ & $7 \cdot 0$ & $25 \cdot 3$ & $6 \cdot 8$ & $27 \cdot 7$ & 7.9 & $27 \cdot 0$ & $7 \cdot 7$ & $24 \cdot 2$ & $7 \cdot 1$ \\
\hline $\mathrm{Ca}(\mathrm{mg} / \mathrm{d})$ & 432.7 & $170 \cdot 0$ & $642 \cdot 7 \S$ & $234.4 \S$ & $675.6 \S$ & $247.9 \S$ & 514.5 & $199 \cdot 6$ & 461.6 & 198.9 \\
\hline$P(\mathrm{mg} / \mathrm{d})$ & $799 \cdot 8$ & $218 \cdot 3$ & $910 \cdot 7 \S$ & $222 \cdot 7 \S$ & $954.4 \S$ & $245 \cdot 1 \S$ & 899.9 & 249.9 & 824.4 & $238 \cdot 2$ \\
\hline Ca:P (mg:mg) & 0.53 & 0.13 & $0.70 \S$ & $0.19 \S$ & $0.71 \S$ & $0.20 \S$ & 0.57 & 0.15 & 0.55 & 0.15 \\
\hline PRAL (mEq/d) & 24.0 & $7 \cdot 7$ & $26 \cdot 3 \S$ & $8.2 \S$ & $27.5 \S$ & $9.0 \S$ & $27 \cdot 1$ & 9.4 & 24.1 & $8 \cdot 3$ \\
\hline Ca:protein (mg:g) & $8 \cdot 1$ & $2 \cdot 3$ & $11.2 \S$ & $3.6 \S$ & $11.5 \S$ & $3.9 \S$ & $8 \cdot 6$ & $2 \cdot 6$ & 8.5 & $2 \cdot 9$ \\
\hline
\end{tabular}

BMC, bone mineral content; BA, bone area; BMD, bone mineral density; PRAL, potential renal acid load.

*Median instead of mean, lowest quartile and highest quartile instead of SD.

thinstead of mean, \% instead of SD.

thelling suplied

$\S$ Including nutrients from supplied milk for both intervention groups. 
PF $(\beta=-10 \cdot 2, P=0 \cdot 01)$ and DF $(\beta=-4 \cdot 82, P<0 \cdot 01)$, BA accrual at PF $(\beta=-9 \cdot 11, P<0.01)$, as well as BMD accrual at $\mathrm{DF}(\beta=-3 \cdot 18, P<0 \cdot 01)$. Similar trends were revealed when analyses were conducted separately in control group subjects who were representative of urban girls in China (data not shown). The association still existed after controlling for $\mathrm{P}$ intake in all subjects or in control group subjects only.

When similar analyses were carried out during the milk supplementation period over the first 2 years, protein intake had significantly negative effects on BMC accrual at TB, PF and $\mathrm{DF}$, on $\mathrm{BMD}$ accrual at $\mathrm{DF}$, and on $\mathrm{BA}$ accrual at $\mathrm{PF}$ and DF $(\beta=-4.80$ to -14.6 , all $P<0.05)$; however, the effects of $\mathrm{Ca}$ intake were $\mathrm{NS}$ on bone mass accrual at all the sites measured during the supplementation period.

\section{Animal protein v. plant protein}

Dietary protein intake from animal sources and from plant sources was assessed. Protein intake from plant sources was 29.2 (SD 13.4) g/d on average in all subjects over 5 years, while protein intake from animal sources ranged between 29.4 (SD 13.4) and 34.4 (SD 13.3) g/d at different periods with or without supplied milk in both intervention groups, and 29.7 (SD 13.4) g/d in the control group (Table 3).

After controlling for $\mathrm{Ca}$ intake at each survey point, baseline bone mass and pubertal stage, PA level and age at each survey, as well as group, time, interaction between time and group, and clustering by school, dietary animal protein intake had a significant negative effect on BMC accrual at DF $(\beta=-1.36, P=0.02)$ and $\operatorname{PF}(\beta=-1.09, P=0.02)$, and on BMD accrual at DF $(\beta=-0.86, P=0.02)$. However, plant protein had no effect on bone mass at PF or DF (model 2 in Fig. 1) after adjustment. The effect of plant protein or animal protein intake on total body bone mass was NS. Moreover, given similar $\mathrm{Ca}$ intake and total protein intake, the percentage of total protein as animal protein had no effect on bone mass accrual at total body or forearm after similar adjustment (data not shown).

\section{Protein from different food groups}

As shown in Table 4 for model 3, food sources of protein were categorised into thirteen groups, namely cereals, legumes, vegetables, fruits, nuts, ice confections, candies, beverages and condiments for plant protein intake, as well as meats, eggs, seafood, milk and milk products for animal protein intake. After controlling for $\mathrm{Ca}$ intake at each survey and other potential confounders indicated as above, protein sources from thirteen food groups were assessed by backward elimination regression. Negative associations were observed between protein intake from meat and BMC accrual at TB $(\beta=-0.22, P=0.09)$ and $\mathrm{PF}(\beta=-0.63, P<0.01)$, BMD accrual at DF $(\beta=-0.28, P=0.08)$ and $\mathrm{BA}$ accrual at $\mathrm{PF}$ $(\beta=-0 \cdot 69, P<0 \cdot 01)$. Similarly, the negative effects of protein from eggs were also observed significantly for BMC accrual $(\beta=-0.25, P<0.01)$, BMD accrual $(\beta=-0.12$, $P=0.04)$ and BA accrual $(\beta=-0.19, P=0.01)$ at DF. Overall, no negative effects were observed from protein from milk and milk products. 
Table 3. Food source of background protein intake, for all subjects, from baseline to the end of study (Mean values and standard deviations)

\begin{tabular}{|c|c|c|c|c|c|c|c|c|c|c|}
\hline & \multicolumn{2}{|c|}{ Baseline } & \multicolumn{2}{|c|}{12 months later } & \multicolumn{2}{|c|}{24 months later } & \multicolumn{2}{|c|}{48 months later } & \multicolumn{2}{|c|}{60 months later } \\
\hline & Mean & SD & Mean & SD & Mean & SD & Mean & SD & Mean & SD \\
\hline \multicolumn{11}{|l|}{ Animal food $(\mathrm{g} / \mathrm{d})$} \\
\hline Seafood $(g / d)$ & $3 \cdot 38$ & 4.40 & $2 \cdot 88$ & $4 \cdot 17$ & 3.79 & $5 \cdot 69$ & 3.50 & $5 \cdot 47$ & $3 \cdot 64$ & 4.84 \\
\hline Meat $(g / d)$ & $15 \cdot 3$ & $10 \cdot 3$ & $16 \cdot 9$ & $10 \cdot 9$ & $16 \cdot 4$ & $10 \cdot 2$ & $19 \cdot 6$ & $11 \cdot 3$ & $17 \cdot 9$ & $10 \cdot 3$ \\
\hline Eggs (g/d) & 4.84 & 3.52 & 4.87 & 3.36 & 4.08 & $3 \cdot 61$ & 4.41 & 3.41 & 3.87 & 3.13 \\
\hline Milk and milk products $(\mathrm{g} / \mathrm{d})$ & 4.00 & $2 \cdot 96$ & $10 \cdot 66^{*}$ & $3 \cdot 56^{\star}$ & $10 \cdot 42^{*}$ & $3.45^{*}$ & $5 \cdot 74$ & $3 \cdot 88$ & $5 \cdot 32$ & 4.09 \\
\hline \multicolumn{11}{|l|}{ Plant food $(g / d) \dagger$} \\
\hline Cereals $(g / d)$ & $19 \cdot 7$ & $4 \cdot 8$ & $18 \cdot 8$ & $5 \cdot 0$ & $20 \cdot 7$ & $5 \cdot 7$ & $19 \cdot 7$ & $5 \cdot 8$ & $18 \cdot 0$ & 5.1 \\
\hline Vegetables $(\mathrm{g} / \mathrm{d})$ & 2.91 & 1.81 & $2 \cdot 82$ & 1.62 & 3.01 & 1.86 & $3 \cdot 15$ & 1.89 & 2.93 & 1.71 \\
\hline Legumes $(\mathrm{g} / \mathrm{d})$ & $2 \cdot 11$ & 2.50 & $2 \cdot 10$ & 2.99 & $2 \cdot 12$ & 2.79 & $2 \cdot 29$ & $2 \cdot 87$ & 1.77 & $2 \cdot 51$ \\
\hline
\end{tabular}

* Including protein from supplied milk for both intervention groups.

$\dagger$ Protein intakes from nuts, fruit, beverages, ice confections, candies or condiments were less than $1 \mathrm{~g} / \mathrm{d}$, separately, and were not listed in the table.

\section{Other indices}

The association between bone mass accretion and total body acid load, expressed as PRAL in the diet, was analysed separately in model 4 or model 5 indicated in Table 5 to further explain the effect of protein intake on bone mass accrual. Mean daily PRAL was as high as 24.1 (SD 8.3) to 27.5 (SD 9.0 ) $\mathrm{mEq} / \mathrm{d}$ over the 5 years (Table 1). After controlling for potential confounders as indicated earlier, PRAL had a negative effect on BMD at DF $(\beta=-1 \cdot 20, P=0.01)$ but no effect on other indices or at other positions.

The average Ca:protein ratio (mg:g) was only 8.1 (SD 2.3) to 11.5 (SD 3.9) over the 5 years. The Ca:protein ratio was positively associated with $\mathrm{BMD}$ at $\mathrm{DF}(\beta=1.51, P=0.02)$ and with $\mathrm{BA}$ at $\mathrm{PF}(\beta=2 \cdot 14, P=0.04)$, but not with TB bone mass indices after controlling for $\mathrm{Ca}$ intake, PA level and age at each survey, baseline bone mass and pubertal stage, as well as group, time, interaction between time and group and clustering by school.

The average urine Ca:creatinine ratio $(\mathrm{mmol} / \mathrm{mmol})$ was 0.135 (SD 0.156) at baseline and 0.100 (SD 0.168) at 12 months from baseline. After controlling for group, time, age, PA level and baseline pubertal stage, urine Ca:creatinine ratio was not associated with $\mathrm{Ca}$ intake or protein intake, and neither PRAL nor bone mass accrual at any site measured (data not shown).

\section{Discussion}

In the present study of Chinese pubertal girls during the period from 10 to 15 years of age, bone mass accretion was considerable. BMC accrual was positively associated with longitudinal $\mathrm{Ca}$ intake, but negatively associated with protein intake at TB, DF or PF after controlling for potential confounders. Protein from animal foods had significantly negative effects on $\mathrm{BMC}$ accrual at DF or PF when protein intakes were categorised as from animal or plant food sources. Positive associations were observed between Ca:protein ratio and bone mass accrual at the forearm, but not for the total body.

Generally speaking, subjects in the present study were typical Chinese urban girls in this age group when compared with subjects in the 2002 China National Nutrition and Health Survey ${ }^{(29)}$, having low $\mathrm{Ca}$ intakes and moderate protein intakes. For instance, Ca intake was about $454 \mathrm{mg} / \mathrm{d}$ on average in the control group who were typical urban girls from 10 to 15 years old in the present study. Although this was slightly higher than the average $\mathrm{Ca}$ level of Chinese urban girls aged $11-13$ years $(334 \mathrm{mg} / \mathrm{d})$ in the 2002 China National Nutrition and Health Survey, it was still less than half the suggested $1000 \mathrm{mg} / \mathrm{d}$ for this age group ${ }^{(9)}$. Their protein intakes (about $55.9 \mathrm{~g} / \mathrm{d}$ ) were approaching the adequate level according to the recommendation $(65-80 \mathrm{~g} / \mathrm{d})$ for this age group in the Chinese dietary recommended intakes ${ }^{(8)}$, and only $10.4 \%$ of


Fig. 1. Effect of protein intake from animal or plant food on bone mass in all subjects* $† \ddagger$ (model 2$)$. *Analysis with linear mixed model adjusted for calcium intake, physical activity level and age at each survey, bone mass and pubertal stage at baseline, as well as group, time, interaction between time and group, and clustering by schools. †All continuous variables were transformed to natural logarithms. $¥$ Protein from supplementation milk was included as part of animal protein at 12


forearm. 
Table 4. Effects of protein intake from influential food sources on bone mass accrual in all subjects (model 3$)^{\star} \dagger \ddagger$ ( $\beta$ Values with their standard errors)

\begin{tabular}{|c|c|c|c|c|c|c|c|c|c|}
\hline & \multicolumn{3}{|c|}{ Total body } & \multicolumn{3}{|c|}{ Proximal forearm } & \multicolumn{3}{|c|}{ Distal forearm } \\
\hline & $\beta$ & SE & $P$ & $\beta$ & SE & $P$ & $\beta$ & SE & $P$ \\
\hline \multicolumn{10}{|l|}{ BMC } \\
\hline Meats & -0.22 & 0.13 & 0.09 & -0.63 & 0.21 & $<0.01$ & - & - & - \\
\hline Eggs & - & - & - & - & - & - & -0.25 & 0.10 & $<0.01$ \\
\hline Fruits & - & - & - & - & - & - & -0.23 & $0 \cdot 10$ & 0.02 \\
\hline Sugar & - & - & - & 0.17 & 0.08 & 0.03 & - & - & - \\
\hline Ice confections & 0.09 & 0.05 & 0.06 & - & - & - & - & - & - \\
\hline Beverages & & & & 0.15 & 0.09 & 0.08 & & & \\
\hline \multicolumn{10}{|l|}{ BMD } \\
\hline Meat & & & & & & & -0.28 & $0 \cdot 16$ & 0.08 \\
\hline Eggs & 0.08 & 0.04 & 0.04 & - & - & - & -0.12 & 0.06 & 0.04 \\
\hline Vegetables & -0.34 & 0.14 & 0.01 & - & - & - & 0.34 & 0.20 & 0.08 \\
\hline Fruits & - & - & - & 0.11 & 0.05 & 0.04 & -0.12 & 0.06 & 0.06 \\
\hline Nuts & - & - & - & 0.07 & 0.04 & 0.08 & - & - & - \\
\hline Condiments & - & - & - & - & - & - & 0.13 & 0.07 & 0.08 \\
\hline \multicolumn{10}{|l|}{ BA } \\
\hline Meats & - & - & - & -0.69 & 0.27 & $<0.01$ & - & - & - \\
\hline Eggs & - & - & - & - & - & - & -0.19 & 0.05 & 0.01 \\
\hline Cereals & & & & & & & 1.69 & 0.59 & 0.04 \\
\hline Sugar & - & - & - & 0.21 & 0.10 & 0.04 & - & - & - \\
\hline Beverages & - & - & - & $0 \cdot 21$ & 0.11 & 0.07 & - & - & - \\
\hline Ice confections & 0.10 & 0.04 & 0.03 & - & - & - & - & - & - \\
\hline Condiments & -0.12 & 0.06 & 0.04 & - & - & - & - & - & - \\
\hline
\end{tabular}

BMC, bone mineral content; BMD, bone mineral density; BA, bone area.

${ }^{*}$ All continuous variables were transformed to natural logarithms and then multiplied by $100, \beta$ represents the percentage change in the dependent variable associated with double intake of each nutrient after control for other confounders.

† Analysis with linear mixed model adjusted for $\mathrm{Ca}$ intake, age and physical activity level at each survey, baseline bone mass and pubertal stage, time, group, the interaction between time and group, and clustering by schools.

$\ddagger$ All nutrient intakes were included in initial model, and followed by backward elimination with $P \leq 0 \cdot 1$ as the standard for retention - excluded by the regression model.

the subjects consumed less than $50 \%$ of the recommendation for protein intake. Their average protein intake per body weight was 1.36 (SD 0.53$) \mathrm{g} / \mathrm{kg}$ per $\mathrm{d}$.

\section{Calcium}

As previously reported ${ }^{(18)}$, the present longitudinal study showed that increased $\mathrm{Ca}$ intake had positive effects on bone mass accrual at total body, proximal forearm and distal forearm ${ }^{(18)}$. Similar results were also reported by Bounds et al. ${ }^{(17)}$ in a longitudinal study of white American boys and girls from $2 \cdot 3$ to 8 years old with relatively high $\mathrm{Ca}$ intakes $(857 \mathrm{mg} / \mathrm{d})$. Moreover, most $\mathrm{Ca}$ supplementation trials in children and adolescents (although relatively short term, of 1-3 years except for one study over 7 years ${ }^{(30)}$ ) also showed an overall positive effect of $\mathrm{Ca}$ on bone mass accrual of $1-6 \%$ for the total body and $1-10 \%$ at regional skeleton sites, compared with placebos.

During adolescence, the requirement of $\mathrm{Ca}$ for growth and bone mass accrual, as well as absorption of $\mathrm{Ca}$, is higher than at any other time of life. Female adolescents tend to have higher $\mathrm{Ca}$ absorption efficiency for bone growth and lower urinary and faecal $\mathrm{Ca}$ excretion than adults ${ }^{(31)}$, especially 1 year before and after menarche ${ }^{(32)}$. However, during that period of rapid skeletal growth in children and adolescents, $\mathrm{Ca}$ intake is often inadequate, especially in Chinese adolescent girls. Although children with habitually low $\mathrm{Ca}$ intakes during puberty show increased absorption and decreased excretion of $\mathrm{Ca}^{(10)}$, the data of Abrams et al. indicated that dietary $\mathrm{Ca}$ of less than $500 \mathrm{mg} / \mathrm{d}$ was insufficient to achieve maximum bone mass accrual. The average $\mathrm{Ca}$ intakes in the present study were far below that considered necessary for optimal bone mass accrual in Chinese pre-pubertal girls.

\section{Protein}

The effect of dietary protein intake on bone mass accrual is complex. On one hand, it has been suggested in a paired

Table 5. The association between calcium:protein or potential renal acid load (PRAL) with bone mass accrual in all subjects (models 4 and 5$)^{\star} \dagger$

( $\beta$ Values with their standard errors)

\begin{tabular}{|c|c|c|c|c|c|c|}
\hline & \multicolumn{3}{|c|}{ Ca:protein } & \multicolumn{3}{|c|}{ PRAL } \\
\hline & $\beta$ & SE & $P$ & $\beta$ & SE & $P$ \\
\hline \multicolumn{7}{|c|}{ Total body } \\
\hline BMC & 0.29 & 0.57 & 0.61 & -0.05 & 0.43 & 0.91 \\
\hline BA & -0.66 & 0.54 & 0.22 & 0.31 & 0.41 & 0.45 \\
\hline BMD & 0.51 & 0.47 & 0.27 & -0.09 & 0.35 & 0.79 \\
\hline \multicolumn{7}{|c|}{ Proximal forearm } \\
\hline $\mathrm{BMC}$ & 1.38 & 0.85 & 0.11 & -0.58 & 0.63 & 0.35 \\
\hline BA & $2 \cdot 11$ & 1.09 & 0.04 & -0.82 & 0.80 & 0.31 \\
\hline BMD & -0.67 & 0.54 & 0.21 & 0.08 & 0.39 & 0.84 \\
\hline \multicolumn{7}{|c|}{ Distal forearm } \\
\hline BMC & 1.38 & 0.85 & 0.11 & -0.58 & 0.63 & 0.35 \\
\hline BA & 0.36 & 0.63 & 0.57 & 0.42 & 0.46 & 0.36 \\
\hline BMD & 1.51 & 0.66 & 0.02 & -1.20 & 0.48 & 0.01 \\
\hline
\end{tabular}

$\mathrm{BMC}$, bone mineral content; BA, bone area; BMD, bone mineral density.

*Analysis with linear mixed model adjusted for Ca intake, physical activity level and age at each survey, bone mass and pubertal stage at baseline, group, time, interaction between time and group, and clustering by schools.

†All continuous variables were transformed to natural logarithms. 
study with young women and postmenopausal women measured by dual stable isotopic methodology that moderate dietary protein intake might promote greater intestinal $\mathrm{Ca}$ absorption, compared with a low protein intake ${ }^{(15,33)}$. According to Cadogan ${ }^{(34)}$, an increase in dietary protein in healthy children and adolescents may also induce an increase in blood insulin-like growth factor-1 concentration, which might stimulate osteoblast activity and promote bone mineralisation. On the other hand, higher dietary protein intake, particularly animal protein, is associated with increased urinary $\mathrm{Ca}$ excretion by increasing the total acid load from protein metabolism ${ }^{(35-37)}$. The sulphur-containing amino acids in protein, the main part of the dietary acid load, could reduce the blood $\mathrm{pH}$ and result in an increase in bone resorption ${ }^{(37)}$. For instance, a study by Kerstetter et al. ${ }^{(38)}$ in young Western women found that a high protein intake increased urinary excretion of $\mathrm{Ca}$ as well as $\mathrm{N}$-telopeptides (bone resorption bio-marker), which suggests that there is increased bone resorption with higher protein intake.

In the present study, using Coles's model ${ }^{(28)}$, it is predicted that a theoretical doubling of protein intake might decrease BMC accrual by $4.82 \%$ at DF, by $10.2 \%$ at $\mathrm{PF}$ or by $1.92 \%$ for the TB, lower BMD accrual by $3.18 \%$ at DF, or reduce BA accrual by $9.11 \%$ at PF in Chinese pubertal girls from 10 to 15 years old. Furthermore, applying the same model $^{(28)}$, a hypothetical doubling of protein intake from animal food could potentially decrease BMC accrual over 5 years by $1.09 \%$ at PF or by $1.36 \%$ at DF, or lessen BMD accrual by $0.86 \%$ at DF given similar Ca intake, PA level, age and baseline BMC and pubertal development.

In the present study, longitudinal PRAL reached $24 \cdot 1$ (SD 8.3 ) to 27.5 (SD 9.0) $\mathrm{mEq} / \mathrm{d}$, higher than that in the Dortmund nutritional and anthropometric longitudinally designed study of 720 German children aged $3-18$ years $(6-21 \mathrm{mEq} / \mathrm{d})$ consuming protein at about $40.5-83.8 \mathrm{~g} / \mathrm{d}^{(39)}$. Although their earlier report for 229 healthy children and adolescents aged 6-18 years indicated that children with a higher dietary PRAL had significantly lower BMC at the proximal diaphyseal radius ${ }^{(12)}$, the present study did not observe any significant effect of PRAL on bone mass accrual of total body or proximal forearm, except for the negative effect on BMD at distal forearm. Moreover, we did not observe any association between PRAL or protein intake and urine $\mathrm{Ca}$ :creatinine. On the other hand, a positive effect of $\mathrm{Ca}$ :protein ratio on bone mass accrual was seen for BMD at DF and BA at PF. Heaney ${ }^{(40-42)}$ have suggested that the dietary $\mathrm{Ca}$ :protein ratio required for positive Ca balance should be at least 20:1 (mg:g). In the present study, the ratio of $\mathrm{Ca}$ to protein in the habitual diet was only approximately $8 \cdot 1-11.5$ at different times. We speculate that the observed association between protein intake and bone mass might have been related to the overall low $\mathrm{Ca}$ intakes. Urinary $\mathrm{Ca}$ excretion might be increased by a higher protein intake in line with the suggestion by Weaver et al. that approximately $6 \mathrm{mg}$ dietary $\mathrm{Ca}$ is required to compensate for the urinary $\mathrm{Ca}$ loss related to $1 \mathrm{~g}$ dietary protein intake ${ }^{(43)}$. In that case, it is predicted that on average $55 \mathrm{~g} / \mathrm{d}$ protein intake during the age of $10-15$ years as in the present study would be associated theoretically with a need for an extra $330 \mathrm{mg} / \mathrm{d}$ dietary Ca to compensate for this urinary Ca loss. With low $\mathrm{Ca}$ intakes, a relatively high protein intake could cause great pressure on $\mathrm{Ca}$ urinary loss, i.e. the higher the protein intake, the less $\mathrm{Ca}$ being retained for bone mass accretion.

The study of Bounds et al. ${ }^{(17)}$ with white American children aged 2.3-8 years and the study of Alexy et al. ${ }^{(12)}$ with German children and adolescents aged 6-18 years have shown that longitudinal protein intake was positively associated with BMC at total body or proximal forearm. The average protein intakes in those studies were similar to that in the present study. However, the average Ca intakes $(667-1056 \mathrm{mg} / \mathrm{d})$ were much higher than those in the present study. Compensation for urinary $\mathrm{Ca}$ loss related to protein intake might not cause much pressure on $\mathrm{Ca}$ retention for bone mass accrual with relatively higher $\mathrm{Ca}$ intakes, and protein intake may have been a benefit for bone mass accrual in Caucasian children with high $\mathrm{Ca}$ intake, but a disadvantage in Chinese children with low $\mathrm{Ca}$ intake. The results in the study of Vatanparast et al. ${ }^{(44)}$ with 133 Canadian Caucasian young adults aged 23 years would seem to support this assumption to certain extent: in the case of females at peri-adolescence or early adulthood with adequate $\mathrm{Ca}$ intake (average 1064 or $1247 \mathrm{mg} / \mathrm{d}$ ) in that study, protein intake positively predicted BMC and BMD at total body; whereas at low Ca intake (average 659 and $766 \mathrm{mg} / \mathrm{d}$ ), protein did not have any beneficial effect on bone.

In China, the average $\mathrm{Ca}$ intake has remained at low levels for a long time and, according to serial national nutrition surveys, has even decreased in recent years from $694.5 \mathrm{mg} / \mathrm{d}$ in 1982 to $405.4 \mathrm{mg} / \mathrm{d}$ in 1992 and to $388.8 \mathrm{mg} / \mathrm{d}$ in 2002 . At the same time, although average protein intake remained stable at $66.7 \mathrm{~g} / \mathrm{d}$ in $1982,68.0 \mathrm{~g} / \mathrm{d}$ in 1992 and $66.1 \mathrm{~g} / \mathrm{d}$ in 2002 , consumption of animal food products has increased greatly in recent years from $52.6 \mathrm{~g} / \mathrm{d}$ in 1982 to $102.4 \mathrm{~g} / \mathrm{d}$ in 1992 and to $131.9 \mathrm{~g} / \mathrm{d}$ in 2002 . Thus, protein intake of animal origin has increased, while protein from plant foods has decreased, corresponding to a decline in cereal consumption ${ }^{(8)}$. While these changes may be interpreted as a sign of improved protein nutrition status, their potential negative influence on bone mass accretion should be monitored during growth. For children in China with low Ca intakes, improvements in protein intake should include increased intakes of protein foods rich in Ca. This situation in China might also be a problem in other developing countries where milk intakes are low.

\section{Strengths and limitations of the study}

In the present study, linear mixed models were adopted to analyse the influence of longitudinal dietary intake. This statistical procedure provided a suitable mechanism for modelling the covariance structure associated with repeated measurements, such as bone mass over several years. It could also compensate for missing data points, thus avoiding the need to eliminate subjects with incomplete data records.

Dual-energy X-ray absorptiometry was used in the present research due to its high accuracy, precision and safety. However, BMD measured by X-ray absorptiometry estimates areal $\mathrm{BMD}$, not volumetric BMD. So BA and BMC were used to evaluate bone mass accretion. Moreover, dietary intakes determined by questionnaires are less accurate than other parameters such as bone variables, which can be measured with comparatively high accuracy. Therefore, associations between diet and other variables must be viewed with caution. Finally, the 
decline in numbers of participants over time might have had a small limiting effect on the outcome of statistical analysis.

In conclusion, it was observed that higher background $\mathrm{Ca}$ intake appeared to have a positive effect on bone mass accrual, while higher protein intakes appeared to have a negative effect on bone mass accrual in Chinese pubertal girls, perhaps in association with their low $\mathrm{Ca}$ intakes. Further research is needed to confirm the effect of dietary protein intake, or the sources of protein, on bone mass accrual in children and adolescents of various ethnic groups and with varying $\mathrm{Ca}$ intakes.

\section{Acknowledgements}

We thank the staff of Beijing Xicheng Student Health Institute and the Department of School Nutrition for their help with organising the fieldwork, especially Dr X. Zhang, Dr L. Zhang and Dr Y. Tong. We also thank Dr J. Liu, Dr Q. Ouyang and Dr D. Z. Wen from Beijing No. 304 Army Hospital for their supports on bone densitometry; Dr T. A. Dobbins of the School of Public Health, University of Sydney for advice on the mixed-model analysis. We are grateful to the support of all the school principals and teachers involved, and the cooperation of all the participating students and their parents.

Q. Z. was involved in data collection and analysis, and drafted the manuscript. K. Z., L. H. F. and X. H. were involved in data collection. G. M. and X. D. were involved in the conception and design of the study. H. G. and D. R. F. were involved in conception, design and interpretation of the study. All authors contribute to the writing of the manuscript. All authors have declared that no conflicts of interest exist. The project was supported by the Australian Dairy Research and Development Corporation (now known as Dairy Australia), the Nestle Foundation and Danone Institute, China.

\section{References}

1. Zhao D, Wu H \& Liu Z (2004) The epidemiology of osteoporosis in China. Chin J Osteoporos 10, 614-618.

2. Nguyen TV, Maynard LM, Towne B, et al. (2001) Sex differences in bone mass acquisition during growth: the Fels longitudinal study. J Clin Densitom 4, 147-157.

3. Bachrach L (2001) Acquisition of optimal bone mass in childhood and adolescence. Trends Endocrinol Metab 12, 22-28.

4. Fässler A \& Bonjour J (1995) Osteoporosis as a pediatric problem. Pediatr Clin North Am 42, 811-824.

5. Ilich J, Badenhop N \& Matkovic V (1996) Primary prevention of osteoporosis: pediatric approach to disease of the elderly. Womens Health Issues 6, 194-203.

6. Goulding A, Cannan R, Williams S, et al. (1998) Bone mineral density in girls with forearm fractures. J Bone Miner Res 13, $143-148$.

7. Heaney RP, Abrams S, Dawson-Hughes B, et al. (2000) Peak bone mass. Osteoporos Int 11, 985-1009.

8. Zhai F \& Yang X (2006) Report of China National Nutrition and Health Survey in 2002 II: Dietary Intake. Beijing: People's Health Publishing House.

9. Chinese Nutrition Society (2000) Chinese DRIs. Beijing: Chinese Light Industry Press.

10. Lee WTK, Cheng JCY, Jiang J, et al. (2002) Calcium absorption measured by stable calcium isotopes $\left({ }^{42} \mathrm{Ca} \&{ }^{44} \mathrm{Ca}\right)$ among northern Chinese adolescents with low vitamin D status. J Orthopaed Surg 10, 61-66.

11. Abrams S, Griffin I, Hicks P, et al. (2004) Pubertal girls only partially adapt to low dietary calcium intakes. J Bone Miner Res 19, 759-763.

12. Alexy U, Remer T, Manz F, et al. (2005) Long-term protein intake and dietary potential renal acid load are associated with bone modeling and remodeling at the proximal radius in healthy children. Am J Clin Nutr 82, 1107-1114.

13. Abelow B, Holford $T$ \& Insogna K (1992) Cross-cultural association between dietary animal protein and hip fracture: a hypothesis. Calcif Tissue Int 50, 14-18.

14. Sebastian A, Harris S, Ottaway J, et al. (1994) Improved mineral balance and skeletal metabolism in postmenopausal women treated with potassium bicarbonate. $N$ Engl J Med 330, 1776-1781.

15. Hunt JR, Johnson LK \& Roughead ZF (2009) Dietary protein and calcium interact to influence calcium retention: a controlled feeding study. Am J Clin Nutr 89, 1357-1365.

16. Munger RG, Cerhan JR \& Chiu BC-H (1999) Prospective study of dietary protein intake and risk of hip fracture in postmenopausal women. Am J Clin Nutr 69, 147-152.

17. Bounds W, Skinner J, Carruth BR, et al. (2005) The relationship of dietary and lifestyle factors to bone mineral indexes in children. J Am Diet Assoc 105, 735-741.

18. Du X, Zhu K, Trube A, et al. (2004) School-milk intervention trial enhances growth and bone mineral accretion in Chinese girls aged 10-12 years in Beijing. Br J Nutr 92, 159-168.

19. Zhu K, Zhang Q, Foo LH, et al. (2006) Growth, bone mass, and vitamin D status of Chinese adolescent girls 3 y after withdrawal of milk supplementation. Am J Clin Nutr 83, 714-721.

20. Institute of Nutrition and Food Hygiene (1991) Food Composition. Beijing: People's Health Publishing House.

21. Department of Health (1991) Dietary Reference Values for Food Energy and Nutrients for the United Kingdom. Report on Health and Social Subjects no. 41. London: HM Stationery Office.

22. He W, Du X \& Greenfield H (1997) CAVD, A Survey System using Epi Info. Beijing: Chinese Academy of Preventive Medicine.

23. Liu A, Ma G, Zhang Q, et al. (2003) The reliability and validity of a 7-day physical activity questionnaire for elementary students. Chin J Epidemiol 24, 901-904.

24. Ainsworth B, Haskell W, Leon A, et al. (1993) Compendium of physical activities: classification of energy costs of human physical activities. Med Sci Sports Exerc 25, 1-80.

25. Ainsworth B, Haskell W, Whitt M, et al. (2000) Compendium of physical activities: an update of activity codes and MET intensities. Med Sci Sports Exerc 32, S498-S504.

26. Tanner J (1962) Growth at Adolescence, 2nd ed. Oxford: Blackwell Scientific Publications.

27. Kalkwarf H, Khoury J, Bean J, et al. (2004) Vitamin K, bone turnover, and bone mass in girls. Am J Clin Nutr 80, 1075-1080.

28. Cole T (2000) Sympercents: symmetric percentage differences on the $100 \log (\mathrm{e})$ scale simplify the presentation of $\log$ transformed data. Stat Med 19, 3109-3125.

29. Wang DL (2005) Report of China National Nutrition and Health Survey in 2002. I: Total Report. Beijing: People's Health Publishing House.

30. Matkovic V, Badenhop-Stevens N, Ha E-J, et al. (2004) Nutrition and Bone Health in Children and Adolescents. Totowa, NJ: Humana Press, Inc.

31. O'Brien K, Abrams S, Liang L, et al. (1996) Increased efficiency of calcium absorption during short periods of inadequate calcium intake in girls. Am J Clin Nutr 63, 579-583.

32. Matkovic V, Goel PK, Badenhop-Stevens NE, et al. (2005) Calcium supplementation and bone mineral density in females from childhood to young adulthood: a randomized controlled trial. Am J Clin Nutr 81, 175-188. 
33. Kerstetter J, O'Brien K, Caseria D, et al. (2005) The impact of dietary protein on calcium absorption and kinetic measures of bone turnover in women. J Clin Endocrinol Metab 90, 26-31.

34. Cadogan J, Eastell R, Jones N, et al. (1997) Milk intake and bone mineral acquisition in adolescent girls: randomized, controlled intervention trial. BMJ 315, 1255-1260.

35. Barzel U \& Massey L (1998) Excess dietary protein can adversely affect bone. $J$ Nutr 128, 1051-1053.

36. Fenton TR, Eliasziw M, Lyon AW, et al. (2008) Meta-analysis of the quantity of calcium excretion associated with the net acid excretion of the modern diet under the acid-ash diet hypothesis. Am J Clin Nutr 88, 1159-1166.

37. Remer T (2000) Influence of diet on acid-base balance. Semin Dial 13, 221-226.

38. Kerstetter J, Mitnick M, Gundberg C, et al. (1999) Changes in bone turnover in young women consuming different levels of dietary protein. J Clin Endocrinol Metab 84, 1052-1055.
39. Alexy U, Kersting M \& Remer T (2007) Potential renal acid load in the diet of children and adolescents: impact of food groups, age and time trends. Public Health Nutr 11, $300-306$

40. Heaney R (1993) Protein intake and the calcium economy. J Am Diet Assoc 93, 1259-1260.

41. Heaney R (1993) Nutritional factors in osteoporosis. Annu Rev Nutr 13, 287-316.

42. Heaney R (1998) Excess dietary protein may not adversely affect bone. J Nutr 128, 1054-1057.

43. Weaver C, Proulx W \& Heaney R (1999) Choices for achieving adequate dietary calcium with a vegetarian diet. Am J Clin Nutr 70, 543S-548S.

44. Vatanparast H, Bailey DA, Baxter-Jones ADG, et al. (2007) The effects of dietary protein on bone mineral mass in young adults may be modulated by adolescent calcium intake. J Nutr $\mathbf{1 3 7}$, 2674-2679. 